\title{
POPULIST OUTRAGE, RECKLESS EMPIRICS: A REVIEW OF FAILING LAW SCHOOLS
}

\author{
Michael Simkovic \& Frank McIntyre*
}

\section{INTRODUCTION}

Brian Tamanaha's Failing Law Schools (University of Chicago Press 2012) is a blistering critique of legal education and a rallying cry for radical reform. As readers flip through this well-written sermon, they can practically smell the brimstone. Professor Tamanaha's argument is that legal education has become too expensive to justify its cost, particularly for graduates considering a career in public service, and that this problem can best be addressed by increasing faculty teaching loads, reducing support for legal scholarship, slashing faculty compensation, and reducing the availability of protections such as tenure. He is particularly critical of nonelite law schools, whose graduates on average earn less than graduates of elite schools, but his proposed reforms would leave few unscathed. ${ }^{1}$

Professor Tamanaha's critique of legal education is not without precedent. Similar criticisms of universities have been made by many conservatives. ${ }^{2}$ The importance of Professor Tamanaha's critique of the legal academy is perhaps not its novelty but rather its author's status. Tamanaha is not a raider lobbing bombs across the parapets-he is an inside man: a former law school interim dean, a scholar in the field of legal theory, and a tenured professor at the top-thirty-ranked Washington University in St. Louis. Working from the inside, Tamanaha has the potential to fracture the academy, pitting elite schools against the rest, ${ }^{3}$ big against small, ${ }^{4}$ urban against rural, ${ }^{5}$ private against public; ${ }^{6}$ to pit faculty

\footnotetext{
Michael Simkovic is an Associate Professor of Law at Seton Hall University School of Law. Frank McIntyre is an Assistant Professor of Finance and Economics at Rutgers Business School. Thanks to Steven M. Davidoff, Ronald G. Ehrenberg, Ted Janger, Frank Pasquale, Joe Price, Ted Seto, Richard Squire, and Michael Weinstock for helpful comments and suggestions.

1 Brian Z. TAMANAHA, FAILING LAW Schools 180 (2012) (proposing to cap federal student loans to shrink the resources available to elite law schools such as Harvard and Columbia).

${ }^{2}$ See, e.g., Glenn Harlan Reynolds, The Higher Education Bubble (2012); NaOmi SChaEFer Riley, The FACUlty LOUNGes: AND Other ReAsons Why You Won't Get THE College Education You Paid For (2011); Richard Vedder, Going Broke by Degree: Why College Costs Too Much (2004); William J. Bennett, Op-Ed., Our Greedy Colleges, N.Y. Times, Feb. 18, 1987, at A31.

3 See TAMANAHA, supra note 1, at 21-27 (accusing elite law schools of creating accreditation standards that favor them); $i d$. at 171-72 ("In an elite-focused legal academy and legal profession, to put it frankly, no one cares about these people [who attended mid- and lower ranked schools] or those types of jobs [they do].”).

4 See id. at 180.
} 
against each other-clinicians against researchers, ${ }^{7}$ the young against the experienced,${ }^{8}$ conservatives against liberals $;{ }^{9}$ to pit students against their teachers, ${ }^{10}$ and ultimately to turn the voting public against law students and the legal profession. ${ }^{11}$

Professor Tamanaha started his battle against tenured faculty in the late 1990s when he served as an interim dean of St. John's University School of Law in Queens, New York. ${ }^{12}$ He eliminated summer research stipends for most faculty, forced out some of his colleagues, and held the line on tuition increases for one year. ${ }^{13}$ In Tamanaha's recounting, he rescued the law school from an entrenched gerontocracy of unproductive and overpaid faculty and reversed a slide in its academic ranking. ${ }^{14}$

In Failing Law Schools, Tamanaha generalizes from his early experience at St. John's to conclude that the problem with legal education is that most faculty members are overpaid and unproductive. ${ }^{15}$ Professor Tamanaha argues that scholarly productivity should be a low priority outside a thin firmament of elite schools. ${ }^{16}$

According to Tamanaha, law schools have priced themselves above their economic value, ${ }^{17}$ and prospective students will no longer put up with

5 See id. at $112,131$.

${ }^{6}$ See id. at 184.

7 See id. at 33 ("Despite [clinical teachers'] second-class status..., the pay is good and work conditions are good enough...."); $i d$. at 34 ("Clinicians relentlessly criticize the emphasis on scholarship in law schools, yet now they hanker to do it themselves in order to qualify for tenure."); $i d$. at $48-52,59-60,126,173,175 ; i d$. at 50 (protesting incentive compensation tied to research productivity on the grounds that "[a] mercenary pay-me-to-write quality attaches to these grants" and speculating that research grants suggest a "lack of an intrinsic desire on the part of the scholar to write").

8 See id. at $186-87$.

9 See id. at 35 ("[L]iberal law professors... are the ones staking out the higher cost position" because they "apparently have blinders on" as to the "consequence[s]."); id. at 143 ("Liberal law professors, especially, will be rankled at the suggestion that the key consideration for a prospective law student is to aim at getting a corporate law job.").

${ }^{10}$ See id. at 48 ("[L]aw professors have been doing swimmingly well compared to most lawyers for some time now. . . Even with high salaries, faculties can revolt over money."); id. at 52 (asserting that faculty "have artificially boosted their salaries in classic rent-seeking terms"); id. at 176 ("[E]ntrenched economic interests, especially . . . law professors and law schools, will conspire against [reform].").

11 See id. at 14 (savoring "[a] delicious irony: the preeminent professional organization of lawyers complaining that it must endure an injustice because legal costs are too high"); id. at 107-08 (approvingly quoting a description of indebted law graduates as motivated "by the "single-minded objective of milking the profession for all it is worth" to repay their debts (quoting John R. Kramer, Will Legal Education Remain Affordable, by Whom, and How?, 1987 DUKE L.J. 240, 241)).

12 Id. at $1-3$.

13 Id. at 6-7.

14 Id. at $1-8$. It is difficult for an outsider to assess these claims.

15 Id. at $46-53$.

16 Id. at 60-61.

17 See id. at 107-44. 
it. ${ }^{18}$ When the level of exploitation by the rentier class of law school faculty is revealed to the underclass of students, ${ }^{19}$ the system will either collapse under its own weight or be forced to undertake radical reform..$^{20}$ Or to put it in nonmaterialist terms: repent law professor, for the end is nigh.

\section{TAMANAHA's PROPOSAL: STARVE THE BEAST}

Like any secular revolutionary or radical preacher, Tamanaha closes by laying out a path to salvation. Tamanaha argues that nonelite law schools should transform themselves into the Motel 6 of legal education: ${ }^{21}$ staffed by a low-paid, itinerant workforce of part-time adjuncts; engineered to minimize costs; and focused primarily on serving the needs of the poor ${ }^{22}$ If the professoriate will not voluntarily accept a large pay cut, then some external power should force it upon them: the American Bar Association (ABA) should lower accreditation standards, ${ }^{23}$ or the states should reduce licensing requirements, ${ }^{24}$ and with the floodgates open, free market competition will take care of the rest.

If bar associations and states are not willing to experiment with extensive free-market reforms, Tamanaha hopes that the federal government will cap access to student loans to prevent law students from borrowing against their future earnings to invest in a legal education..$^{25}$

Tamanaha also proposes cuts to federal debt forgiveness programs. Although he describes the lack of legal services for the poor as a crisis, ${ }^{26}$ he worries about federal student loan forgiveness programs - which subsidize graduates who work in public service or who have low incomes because they serve the poor - on the grounds that these programs may require an investment from taxpayers without imposing sufficient pain on professors. ${ }^{27}$

18 Id. at $160-66$.

19 Id. at 51-52 (suggesting that faculty "have artificially boosted their salaries in classic rentseeking terms."); $i d$. at 53 (Law professors' "quality of life is far better than that of lawyers, and we make more money than most lawyers."); id. at 61 ("[S]tudents should not be made to bear a costly burden for faculty research.").

${ }^{20} I d$. at 145 ("[I]nflated employment and salary rates [at graduation or nine months after] posted by law schools helped artificially prop up demand. . . It is an elaborately constructed mirage.”); id. at 18182 ("Schools will be downsized whether they want to or not. ... The age of indulgence for law schools will make way for a time of pain.").

21 This metaphor was first used by Professor Jay Sterling Silver, who defends the value of legal research in his review of Failing Law Schools. Jay Sterling Silver, The Case Against Tamanaha's Motel 6 Model of Legal Education, 60 UCLA L. REV. DisCOURSE 50 (2012).

22 TAMANAHA, supra note 1 , at 173-76.

23 Id. at xii, 12, 41, 173-77.

24 Id. at $176-77$.

25 Id. at $180-81$.

${ }^{26} I d$. at 170 ("[T] $[\mathrm{The}$ poor and lower middle class-go without legal assistance. This is reaching crisis proportions."); see also id. at 174-75.

27 Id. at 124-26, 177-82. After Philip Schrag critiqued Tamanaha's description of federal debt forgiveness programs as imposing "hardship" on graduates, Tamanaha acknowledged his errors and 
Unlike his earlier suggestion of lower standards, which he believes would expand the supply of law graduates and drive down their wages, Tamanaha's proposals to cap loans or terminate federal debt forgiveness programs ${ }^{28}$ would shrink the supply of law graduates, increase the costs of legal services, and reduce opportunities for the poor to attend law school.

It is unclear whether Tamanaha believes the problem is too many law graduates earning too little, ${ }^{29}$ or too few law graduates earning too much. ${ }^{30} \mathrm{It}$ is unclear whether he wants more services for the poor, or wants lower taxes and fewer services. ${ }^{31}$ He supports a variety of changes, some of them contradictory, but all of which seem likely to drain resources from law schools. $^{32}$

\section{TAMANAHA's ERRORS, SELECTIVE CITATIONS, INAPPOSITE COMPARISONS, AND QUESTIONABLE ASSUMPTIONS}

To support his argument that the cost of a legal education exceeds its economic value, Tamanaha compares the earnings of law graduates to college graduates. However, the earnings figures he cites for law graduates and lawyers are generally either at an early stage of their careers when

reiterated his opposition to such programs because they subsidize law schools. Philip G. Schrag, Failing Law Schools: Brian Tamanaha's Misguided Missile, 26 GEO. J. LEGAL ETHICs 387, 400-05 (2013); Brian Tamanaha, What's Wrong with Income Based Repayment in Legal Academia: A Response to Schrag, BALKINIZATION (Nov. 29, 2012, 6:38 PM), http://balkin.blogspot.com/2012/11/whats-wrongwith-income-based-repayment.html. Without apparent irony, Tamanaha proposes a program similar to medical residencies for law graduates. TAMANAHA, supra note 1, at 175. Residencies are partly paid for through Medicare and, therefore, taxes. Ass'N OF AM. Med. Colls., Medicare Payments For Graduate Medical Education: What Every Medical Student, Resident, ANd Advisor NeEdS TO KNOW 2 (2013), available at http://www2.uic.edu/stud_orgs/prof/umsc/documents/ medicaregme2013.pdf. Shifting to a Medicare-like model from an income-contingent, forgivable student-loan model would increase the costs to taxpayers of training each young lawyer because law students would no longer be expected to repay any of the costs of their training.

28 TAMANAHA, supra note 1, at 180-81 ("[S]chools will place a premium on letting in rich folks who don't need to borrow. ... [T] [Tere is no clean solution . . . . All things considered, a hard cap would seem to be the most viable way to control tuition and enrollment ....").

${ }^{29}$ Id. at 179-80 (rejecting an inflation-adjusted, per-student cap on student loans because "law schools can take in more students - as they have been doing - which would exacerbate the difficulty graduates have finding jobs and would increase the total sum of money supplied [to law schools] by the government").

30 See id. at 134 ("Students from middle-class and poor families frightened by the specter of taking on insurmountable debt will increasingly forgo law school. . . Our tuition-scholarship matrix helps the wealthy consolidate their grip on elite legal positions.").

31 See supra notes 26-27 and accompanying text.

32 TAMANAHA, supra note 1, at 27 ("The real enemy of the middle class and poor is the expensive academic model ...."); $i d$. at 178-80 (criticizing federal student loans as "a funding program for law schools" and advocating a cap on loans); id. at 178 ("Losing federal loan eligibility would be the death penalty."). 
earnings are relatively low, ${ }^{33}$ are toward the bottom of the earnings distribution for lawyers, ${ }^{34}$ or are otherwise biased down compared to the earnings figures he cites for college graduates. ${ }^{35}$

Professor Tamanaha overstates the predictive power of starting salaries, and he contradicts his own sources when he states that law graduates' earnings grow slowly and do not typically increase after the first ten years. Tamanaha writes that "[ $\mathrm{t}]$ he earnings of lawyers in this range will increase modestly - about ten years out, average earnings peak and remain flat thereafter ...." ${ }^{36}$ His source, in fact, states: "By far, the biggest gain over the early years of one's career involves those with Professional degrees. Workers with Professional degrees earn 100 percent more in their 40 's than they do in their initial years in the workforce." 37

Carnevale et al. find that earnings of generic professional school graduates do not peak in their mid-thirties but rather in their forties after rapid growth. Other sources also report rapid earnings growth and late earnings peaks. ${ }^{38}$

\section{A. Lifetime Earnings of Graduates}

Tamanaha is at his best when he critiques empirical studies that suggest that generic professional degrees pay off handsomely. ${ }^{39} \mathrm{He}$ correctly points out that such studies were not designed to measure the specific value of a law degree, the outcomes for generic professional degree holders may not reflect those for law degree holders, and law degree holders are not the same as lawyers, since many law school graduates do not practice law. ${ }^{40} \mathrm{He}$ also points out that these studies assume continuous full-time employment, even though many individuals will sometimes work part-time or experience periods of unemployment. ${ }^{41}$

33 See id. at 140 (discussing starting salaries for law graduates); id. at 141 (discussing earnings seven years after graduation from the American Bar Foundation and NALP's After the JD survey).

34 See id. at 139 (comparing median earnings for political science majors to the twenty-fifth percentile of earnings for lawyers).

35 See infra notes 50-59 and accompanying text.

36 TAMANAHA, supra note 1, at 140 (citing ANTHONY P. CARNEVALE ET AL., GEORGETOWN UNIV. CTR. On Educ. \& THE Workforce, The College Payoff: Education, OCCuPATions, Lifetime EARNINGS 5 (2011), available at http://www9.georgetown.edu/grad/gppi/hpi/cew/pdfs/collegepayoffcomplete.pdf).

37 CARNEVAlE ET AL., supra note 36.

38 E.g., Jennifer Cheeseman Day \& Eric C. Newburger, U.S. Census Bureau, The Big PAyofF: EduCATIONAL ATTAINMENT AND SYNTHETIC Estimates OF WORK-LIFE EARNings 4-5, 5 fig.4 (2002), available at http://www.census.gov/prod/2002pubs/p23-210.pdf.

\footnotetext{
39 See TAMANAHA, supra note 1 , at 137-38.

40 Id. at $137-40$.

41 Id. at 138.
} 
In our own recent article, The Economic Value of a Law Degree, ${ }^{42}$ we overcome these previous studies' limitations. Our article tracks earnings for a large sample of law graduates and compares them to earnings for similar college graduates, with appropriate controls for demographic characteristics and innate differences in ability and motivation.

Our most recent data comes from 2013. Although point estimates suggest a reversion in premiums from a peak around 2008, we do not find evidence of structural changes reducing the law degree premium in recent years to below-historical norms. Earnings declined for law graduates, but earnings also declined for college graduates, and law graduates maintained their historical relative advantage. Figure 1 below, excerpted from our recent article, shows the log earnings premium ${ }^{43}$ for law graduates by year. In The Economic Value of a Law Degree, we also consider changes in the earnings premium for recent graduates (age twenty-five to thirty) and similarly find no evidence that the postrecession law earnings premium for this group dropped below normal historical levels. ${ }^{44}$

${ }^{42}$ Michael Simkovic \& Frank McIntyre, The Economic Value of a Law Degree (Harvard Law Sch. Program on the Legal Profession, Research Paper No. 2013-6, Jan. 14, 2014) [hereinafter Simkovic \& McIntyre Working Paper Version 2], available at http://ssrn.com/abstract=2379146.

43 A $\log$ is similar to a percentage. The log premium will be a bit lower than the percent increase in earnings above similar bachelor's degree holders.

44 Our analysis did not include those who graduated after 2008 because data was not available in the U.S. Census Bureau's Survey of Income and Program Participation. However, a supplemental analysis using a sample of young likely law degree holders (professional degree holders excluding those in medicine) from the American Community Survey, including more recent graduates, also did not show evidence of a decline in the earnings premium. MichaEL SimKOVIC \& FRANK MCINTYRE, JD EARNINGS Premium Probably Has Not DeClined for ReCEnt CoHorts (2013) (on file with the Northwestern University Law Review). 
Figure 1: Law Degree Earnings Premiums in Recent Years Are Within Historical Norms - Log Law Degree Earnings Premium, 1996-2013

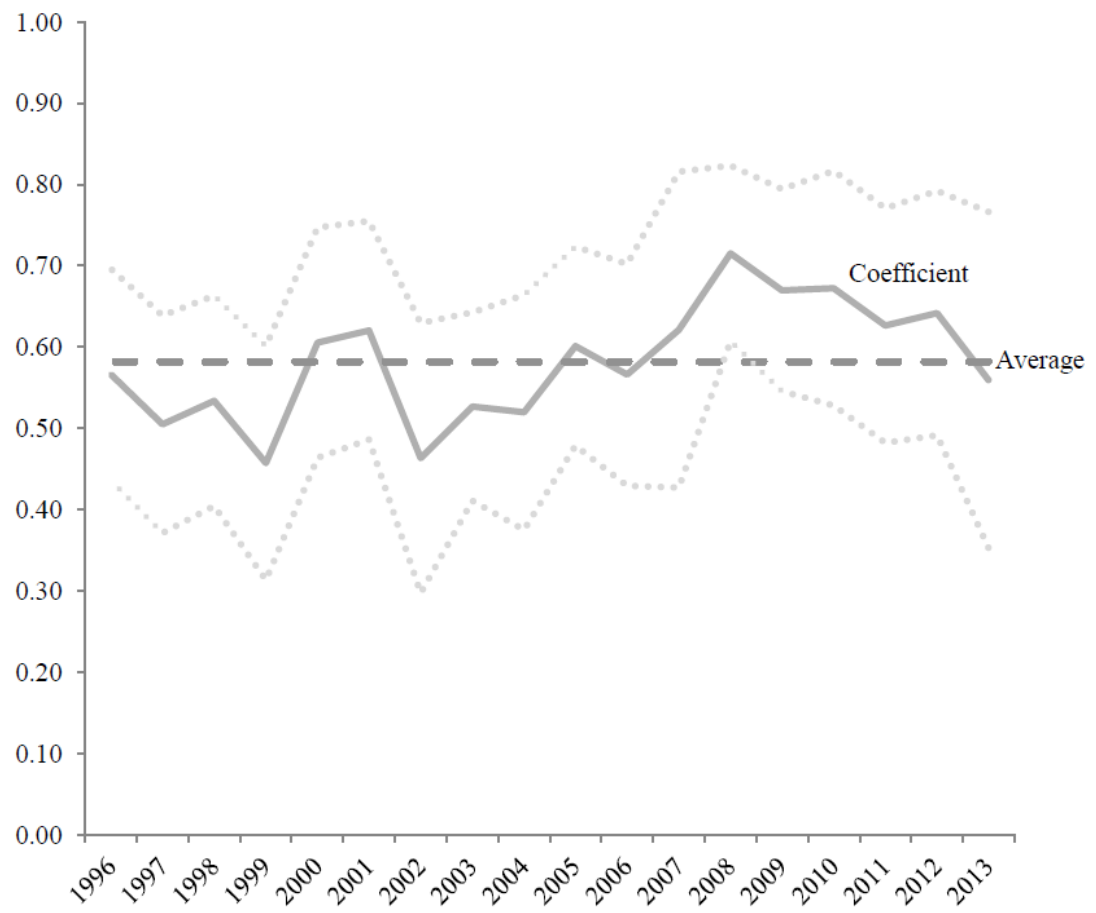

Source: U.S. Census Bureau, Survey of Income and Program Participation; Michael Simkovic \& Frank McIntyre, The Economic Value of a Law Degree.

Note: Solid line is the coefficient. Dotted lines represent $95 \%$ confidence interval. Horizontal dashed line resents multiyear average with each year weighted equally. A joint test rejects the hypothesis that the coefficients are equal across all years $(p<0.001)$.

Comparing lifetime earnings of law degree holders to earnings of similar bachelor's degree holders, we find that the pretax value of a law degree is approximately $\$ 1,030,000$ on average, $\$ 770,000$ at the median, $\$ 430,000$ at the twenty-fifth percentile, and $\$ 1,420,000$ at the seventy-fifth percentile. ${ }^{45}$ These figures include the opportunity costs of foregone wages while in law school and financing costs. ${ }^{46} \mathrm{We}$ also provide separate analyses of earnings for men and women. We find that the value of a law degree at

45 Simkovic \& McIntyre Working Paper Version 2, supra note 42, at 24, 38 tbl.6.

46 These figures are the aggregate economic value of the law degree, in present value terms at the start of law school. Net present value of law degree completion and private benefit to the student can be estimated by subtracting federal taxes (around 30\%) and tuition from the lifetime earnings premium. 
the median is higher for women than for men because of a larger increase in work hours, but at the mean, the value for men and women is similar. ${ }^{47}$

Thus, the value of a law degree typically exceeds its $\operatorname{costs}^{48}$ by hundreds of thousands of dollars. Even at the twenty-fifth percentile, a law degree is typically a profitable investment.

At current price levels, law degrees generally provide an attractive double-digit pretax rate of return. ${ }^{49}$ Legal education is profitable both for students and for the federal government as tax collector and lender. In sum, the evidence simply does not support Professor Tamanaha's thesis.

\section{B. Inconsistent Assumptions About Age, Experience, Work Status, and the Definition of Earnings}

Figure 2 below, abstracted from The Economic Value of a Law Degree, highlights the rapid growth of law degree holder earnings relative to bachelor's degree holder earnings as workers gain experience. The pattern for law degree holders is consistent with the overall pattern for professional degree holders.

47 Id. at 25 . The value at the median is approximately $\$ 860,000$ for women and $\$ 650,000$ for men.

48 After excluding subsidies from state and local governments and deducting grants and scholarships, the average three-year net-tuition cost of a law degree is probably somewhere between $\$ 80,000$ and \$100,000. See Enrollment and Degrees Awarded 1963-2012 Academic Years, A.B.A., http://www.americanbar.org/content/dam/aba/administrative/legal_education_and_admissions_to_the_ bar/statistics/enrollment_degrees_awarded.authcheckdam.pdf (last visited Jan. 14, 2014); Internal Grants and Scholarships Total Dollar Amount Awarded 1991-2012, A.B.A., http:// www.americanbar.org/content/dam/aba/administrative/legal_education_and_admissions_to_the_bar/ statistics/internal_grants_scholarships_awarded.authcheckdam.pdf (last visited Jan. 14, 2014); Law School Tuition 1985-2012, A.B.A., http://www.americanbar.org/content/dam/aba/administrative/ legal_education_and_admissions_to_the_bar/statistics/ls_tuition.authcheckdam.pdf (last visited Jan. 14, 2014).

49 See Simkovic \& McIntyre Working Paper Version 2, supra note 42, at 23-24; supra note 48. 
Figure 2: Law Degree Holders' AnNual EARnings Grow Faster and PeAK LATER than Similar Bachelor's Degree Holders'-Annual Mean Earnings by Degree Type and Age, Ages 26-65

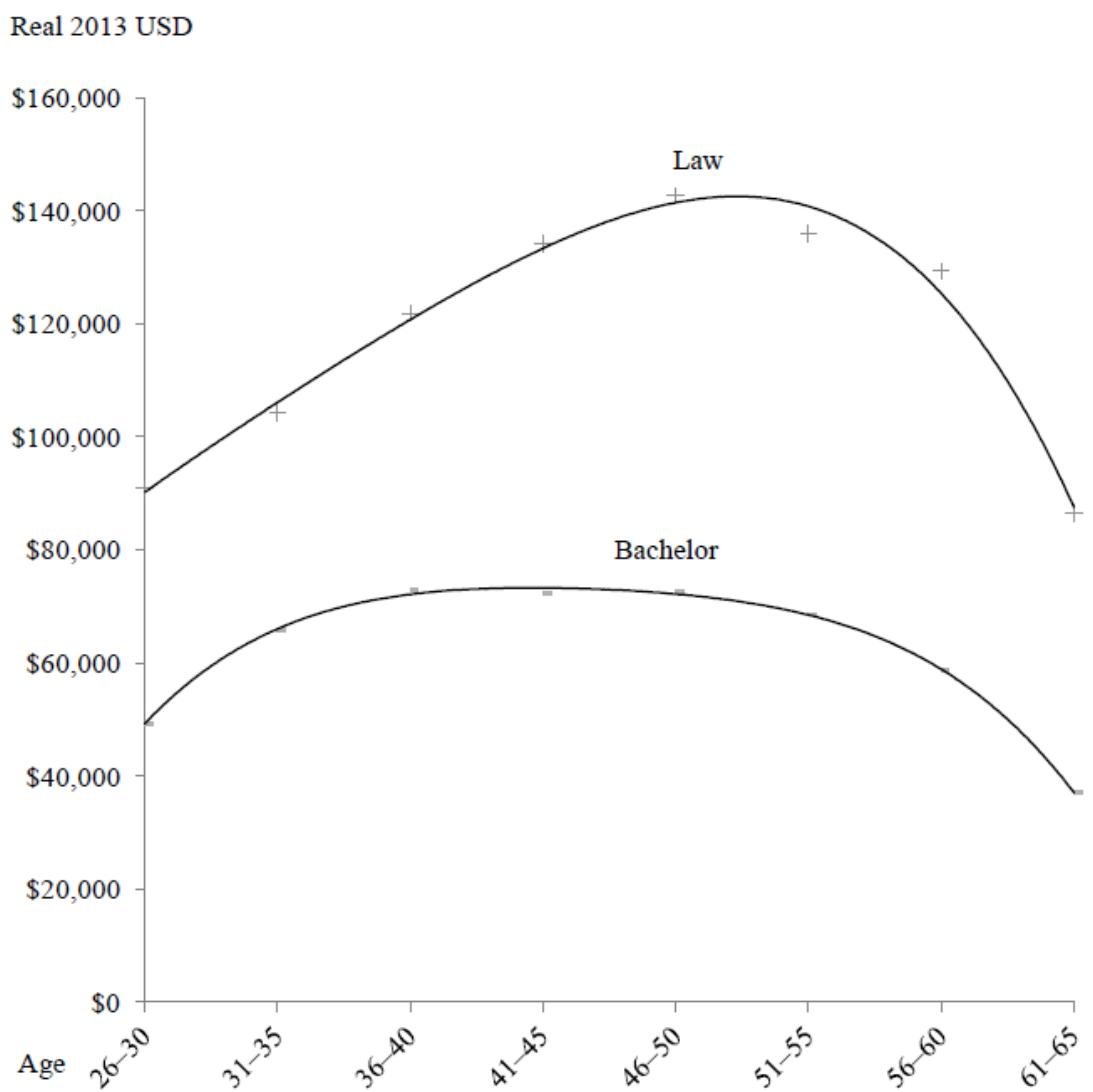

Source: U.S. Census Bureau, Survey of Income Program and Participation; Michael Simkovic \& Frank McIntyre, The Economic Value of a Law Degree.

Note: Includes degree holders who are working, unemployed, or disabled. Calculated by fitting a fourth-order polynomial to average earnings for five-year age blocks.

As several of the studies Professor Tamanaha cites point out, and as our own analysis in The Economic Value of a Law Degree shows, earnings typically peak at middle age, between ages fifty and fifty-five. Professional degree holders typically start out at higher earnings levels than bachelor's degree holders, and they also usually see their earnings increase at a much faster rate and over a longer period of time - that is, professional degree 
holders peak higher and later in life than bachelor's degree holders. ${ }^{50}$ Because starting salaries are not a very good predictor of lifetime earnings, earnings premiums must be estimated at multiple ages or experience intervals.

This illustrates a problem in Professor Tamanaha's analysis. He compares the earnings of terminal bachelors who majored in political science at "midcareer" — at peak earnings, typically in their forties, with around ten to twenty years of work experience ${ }^{52}$ - to the earnings of lawyers at all age and experience levels, and excluding high-earning law firm partners. ${ }^{53}$ Because many law graduates who do not make partner transition to roles other than legal practice after their first few years, Tamanaha's sample disproportionately includes young and inexperienced law graduates.

In addition to mismatching age and experience levels, and excluding law firm partners, Professor Tamanaha mismatches work statuses ${ }^{54}$ exclusively full-time bachelor's degree holders versus mixed part-time and full-time lawyers - in a way that underestimates the earnings of lawyers relative to bachelor's degree holders.

Moreover, Professor Tamanaha splices together inconsistent definitions of earnings from different sources with different sampling and reporting biases. His earnings figures for political science majors include most bonuses ${ }^{55}$ while his earnings figures for lawyers generally exclude them. ${ }^{56}$ This inconsistency will bias averages because, for lawyers and other

50 ANTHONY P. CARNEVAlE ET AL., supra note 36, at 4-5 ("By far, the biggest gain over the early years of one's career involves those with Professional degrees. [They] earn 100 percent more in their 40's than they do in their initial years in the workforce."); DAY \& NEWBURGER, supra note 38.

51 TAMANAHA, supra note 1, at 139 (emphasis added); see also Herwig Schlunk, Mamas Don't Let Your Babies Grow Up to Be .. Lawyers 2 (Vanderbilt Law \& Econ., Working Paper No. 09-29, 2009), available at http://ssrn.com/abstract=1497044 (citing the website Payscale.com, reporting a 2009 midcareer salary of $\$ 77,300$ ( $\$ 83,977$ in 2013 dollars) for political science majors).

52 See PayScale College Salary Report, Methodology Overview, PAYSCALE, http://www.payscale.com/2009-best-colleges/salary-report.asp (last visited Jan. 14, 2014) ("Mid-Career Employees . . . are full-time employees with at least 10 years of experience in their career or field who hold a bachelor's degree and no higher degrees. For the graduates in this data set, the typical (median) mid-career employee is 42 years old and has 15 years of experience.").

53 See TAmANAHA, supra note 1, at 139 (citing Bureau of Labor Statistics data); Occupational Employment Statistics, Frequently Asked Questions, BUREAU LAB. STAT., www.bls.gov/oes/oes_ ques.htm (last modified Nov. 22, 2013) (follow "How are 'employees' defined by the OES survey?" hyperlink) (“"Employees' are all part-time and full-time workers who are paid a wage or salary. The survey does not cover the self-employed [or] owners and partners in unincorporated firms ....”).

54 See supra notes 52 and 53 and accompanying text.

55 See PayScale College Salary Report Methodology, supra note 52 (Salary "[c]ombines base annual salary..., bonuses, profit sharing, tips, commissions, overtime, and other forms of cash earnings, as applicable. Salary does not include equity (stock) compensation . . ..”).

56 See Occupational Employment Statistics, Frequently Asked Questions, supra note 53 (follow "How are 'wages' defined by the OES survey?" hyperlink) (reporting that OES wage data exclude "premium pay" such as "[n]on-production bonuses," but include "[i]ncentive pay," including "[c]ommissions" and "[p]roduction bonuses"). Bonuses to lawyers would likely be classified as 
high-income individuals, bonus compensation can be substantial relative to salary. ${ }^{57}$

Under more consistent assumptions about age, experience, work status, and the definition of earnings, the earnings figures Professor Tamanaha presents as a median for legally inclined college graduates are in fact close to the seventy-fifth percentile for that group. ${ }^{58}$

Due to these problems, Professor Tamanaha ends up comparing the earnings of roughly the seventy-fifth percentile bachelor's degree holders to the earnings of twenty-fifth percentile lawyers. ${ }^{59}$ In other words, Professor Tamanaha asserts that the difference in earnings between law graduates and bachelor's degree holders is largely due to differences in the innate abilities and motivation of the students, and that these differences swamp anything contributed by a law degree. ${ }^{60}$

In The Economic Value of a Law Degree, our analysis of detailed demographic data, test scores, grades, college majors, college costs, and proxies for motivation, family background, and work preferences suggests that ability sorting is modest, accounting for perhaps a $0 \%-10 \%$ earnings premium, whereas the overall earnings premium is on the order of $65 \%-$ $99 \% .^{61}$ That is, the type of person who could have chosen to attend law school might earn slightly more than the typical bachelor's degree holder, even without a law degree. But the disparity in earnings based on observable differences is small and does not change our basic conclusions that law degrees more than pay for themselves.

nonproduction bonuses because they generally are "not directly related to output of an employee or group," as opposed to commissions measured as a percent of sales. GTP Glossary of Pay Terms, BUREAU LAB. STAT., http://www.bls.gov/respondents/gtp/glossary.htm (last modified Oct. 4, 2012).

57 See Joan C. Williams et al., Better on Balance? The Corporate Counsel Work/Life Report, 10 WM. \& MARY J. WOMEn \& L. 367, 430 (2004); William D. Henderson \& David Zaring, Young Associates in Trouble, 105 MICH. L. REV. 1087, 1097 (2007) (book review) (reporting mean 2005 bonuses of $\$ 17,000$ compared to mean salaries of $\$ 143,000)$.

58 Anthony P. Carnevale et al., Georgetown Univ. Ctr. on Educ. \& the Workforce, What's It Worth? The ECONOMiC Value of College Majors 34-37 (2011), available at http://www9.georgetown.edu/grad/gppi/hpi/cew/pdfs/whatsitworth-complete.pdf (reporting median 2009 earnings between $\$ 42,000$ and $\$ 55,000$ ( $\$ 46,000$ to $\$ 60,000$ in 2013 dollars) for full-time workers with a terminal bachelor's who majored in psychology and social work, humanities and liberal arts, law and public policy, and social sciences and seventy-fifth percentile earnings between $\$ 62,000$ and $\$ 87,000$ ( $\$ 67,000$ and $\$ 95,000$ in 2013 dollars)).

59 TAMANAHA, supra note 1, at 139-40 ("Lawyers who end up in the bottom quartile of lawyer earnings, in hindsight, could have... earned the same amount with a bachelor's degree in business, engineering, social science, science, or computers. . . Law students are a smart and motivated bunch so it is reasonable to assume that they would have gotten the average earnings [seventy-fifth percentile or above earnings because of problems with Tamanaha's comparison, discussed above] of their fellow bachelor's degree holders.").

${ }^{60} I d$.

61 Simkovic \& McIntyre Working Paper Version 2, supra note 42, at 8-15, 31 fig.3, 35 tbl.3. We may be underestimating the law degree earnings premium because of response biases in the Survey of Income and Program Participation, or such bias may offset any remaining selection on unobservables. 
Tamanaha concludes that lawyers who do not start their careers in big firms or who graduate from nonelite schools are doomed to penury. ${ }^{62}$ But two of the reports that Tamanaha relies upon contradict his conclusion. ${ }^{63}$ Studies show that as law graduates gain experience, those in the practice settings with the lowest initial earnings experience the most rapid earnings growth. ${ }^{64}$ Similarly, although graduates of low-ranked schools have lower initial earnings, their earnings grow more rapidly than those of graduates of elite schools. ${ }^{65}$

Tamanaha states that law graduates struggle under crushing debt burdens. ${ }^{66}$ But the American Bar Foundation and NALP's After the JD II survey finds that debt levels do not predict job choice, ${ }^{67}$ that most law graduates report that debt has a minimal effect on other major life decisions, ${ }^{68}$ and that law graduates are able to pay down their student loans quickly. ${ }^{69}$

To be sure, After the JD tracks law students who graduated in the early 2000s, when tuition was lower. Nonetheless, publicly available data that we summarize in The Economic Value of a Law Degree shows that former law students who entered repayment more recently continue to be much less likely than former college students or other former advanced degree students to default on their student loans. ${ }^{70}$

62 TAMANAHA, supra note 1, at 140-43 ("At lower-ranked schools only the top 5 percent have a chance" of finding a big-law job that will enable them to pay down their debts.).

63 See Ronit DinOvitzer ET AL., AM. BAR Found. \& NALP FOUND., AFTER THE JD II: SECOND REsults FROM A NATIONAL StUdy OF LEgAl CAREERs (2009) [hereinafter AFTER THE JD II], available at http://www.law.du.edu/documents/directory/publications/sterling/AJD2.pdf; RONIT DinOvitzer ET AL., NALP Found. \& AM. BAR Found., AFTER THE JD: FiRST RESUlTS OF A NATIONAL STUDY OF LEGAL CAREERS (2004) [hereinafter AFTER THE JD], available at http:// www.americanbarfoundation.org/uploads/cms/documents/ajd.pdf.

64 AFTER THE JD II, supra note 63, at 42.

${ }^{65}$ Id. at 44 tbl.5.2 (showing earnings roughly seven years after graduation); AFTER THE JD, supra note 63 , at 44 tbl.5.2 (showing earnings roughly three years after graduation).

66 TAMANAHA, supra note 1, at 125, 134.

67 AFTER THE JD II, supra note 63, at 81-83 ("When we examined the impact of debt on first jobs in 2003, however, we did not find a strong correlation between levels of debt and job choice. This continues to be the case... [even though self-reports suggest that some] respondents nevertheless appear to feel the weight of their debt in a more global way.").

68 Id. at 81 ("[R]espondents do not believe that their educational debt affected their other life choices, such as whether or when to have children or purchase a home.").

69 Although graduates have up to twenty-five years to repay federal student loans under extended and income-contingent repayment plans, and the benefits of a legal education typically accrue over an even longer period, within three years of graduation, $16 \%$ of law graduates in the After the JD study had no educational debt. Four years later, $36 \%$ of those graduates had no education debt. In four years, median debt levels of those with debt dropped from $\$ 70,000$ to $\$ 50,000$, and the percent of graduates with more than $\$ 100,000$ in debt dropped from $21 \%$ to $8 \%$. Id. at $80-82,81$ tbl.10.1, 82 fig.10.1, 82 tbl.10.2.

${ }^{70}$ Michael Simkovic \& Frank McIntyre, The Economic Value of a Law Degree 48 fig.7, tbls.11 \& 12 (Harvard Law Sch. Program on the Legal Profession, Research Paper No. 2013-6, Aug. 14, 2013) 


\section{Reliance on Flawed Studies and Questionable Assumptions}

Professor Tamanaha praises manuscripts by law professors who concur with his conclusions. ${ }^{71}$ But their methodologies suffer from questionable assumptions.

For example, Professor Schlunk's analysis assumes astronomical discount rates, low earnings growth rates, and zero inflation for thirty-five years. $^{72}$ None of these assumptions are empirically or theoretically justifiable. ${ }^{73}$

Most studies by economists have generally used a discount rate between $2.5 \%$ and $3 \% .{ }^{74}$ Some studies have related appropriate discount rates to the actual student loan interest rates faced by prospective students. ${ }^{75}$ Compared with the $3 \%$ discount rates applied in labor market studies by economists and suggested by the real (net-inflation) costs of financing a law degree with federal student loans, ${ }^{76}$ Professor Schlunk applies real discount rates of between $8 \%$ and $27 \% .^{77}$

If Professor Schlunk had used comparable assumptions about discount rates to evaluate the value of a college degree compared to a high school diploma, he would have reached the conclusion that few should go to

[hereinafter Simkovic \& McIntyre Working Paper Version 1], available at http://ssrn.com/ abstract $=2250585$.

71 Tamanaha, supra note 1, at $217 \mathrm{n} .18$ (citing Jim Chen, A Degree of Practical Wisdom: The Ratio of Educational Debt to Income as a Basic Measurement of Law School Graduates' Economic Viability, 38 WM. MitcheLl L. REV. 1185 (2012); Schlunk, supra note 51).

72 Schlunk, supra note 51, at 9-11, 9 n.15.

73 See generally Simkovic \& McIntyre Working Paper Version 2, supra note 42.

74 See, e.g., SANDY BAUM ET AL., COLlEgE BOARD, EdUCATION PAYs 2010, at 12 fig.1.2, available at http://trends.collegeboard.org/sites/default/files/education-pays-2010-full-report.pdf (applying a 3\% discount rate); CARNEVAlE ET AL., supra note 36, at 21 (proposing a $2.5 \%$ discount rate); DAY \& Newburger, supra note 50 (using no discount rate); EdWARd M. GRAMLICH, A Guide to BenEFITCOST ANALYSIS 168 (2d. ed. 1990) (encouraging the use of approximately a 3\% discount rate in benefitcost analysis); Paul Oyer \& Scott Schaefer, Welcome to the Club: The Returns to an Elite Degree for American Lawyers 37 n.18 (Dec. 11, 2012) (unpublished manuscript), available at http://www.law.yale.edu/documents/pdf/LEO/Oyer_WelcometotheClub.pdf ("We believe that 10\% is probably too large a discount factor ....”).

75 See, e.g., James J. Heckman et al., Earnings Functions, Rates of Return and Treatment Effects: The Mincer Equation and Beyond, in 1 HANDBOOK OF THE ECONOMICS OF EDUCATION 307, 313 (Eric A. Hanushek \& Finis Welch eds., 2006) (discussing the traditional view that "[i]f the IRR [internal rate of return] exceeds the interest rate, further investment in education is warranted"); Ronald G. Ehrenberg, An Economic Analysis of the Market for Law School Students 21 (Nat'1 Bureau of Econ. Research, Working Paper No. 2602, 1988), available at http://www.nber.org/papers/w2602.pdf?new_ window $=1$

76 Simkovic \& McIntyre Working Paper Version 1, supra note 70, at 52-55.

77 Herwig Schlunk, Mamas 2011: Is a Law Degree a Good Investment Today?, 36 J. LEGAL Prof. 301, 318 (2012); Schlunk, supra note 51, at 11. 
college. Indeed, given a 30\% nominal discount rate, whether it makes financial sense to complete high school might be debatable. ${ }^{78}$

Professor Chen assumes that the debt-to-income ratios used by mortgage lenders can be applied to law students. ${ }^{79}$ But law graduates experience rapid earnings growth, making debt-to-income ratios at graduation poor predictors.

Moreover, the meaning of financial ratios is context specific. ${ }^{80}$ Chen does not consider actual law student loan performance. ${ }^{81}$ Publicly available data unambiguously show that law students have extremely low default rates relative to other student borrowers even though they have high debt levels. ${ }^{82}$ This was true both before and after federal income-based debt forgiveness programs became available. And because we can see the difference in relative default rates across programs with access to the same loan terms, we can rule out the possibility that more generous terms are driving lower law student defaults.

\section{TAMANAHA'S PROPOSED SOLUTIONS}

Professor Tamanaha's diagnosis is incorrect. But that does not necessarily mean that his prescriptions are. Tamanaha makes a variety of suggestions for reforms of legal education, some of which already exist in certain places. Natural variation in practices among law schools and differences in regulations between states present opportunities to evaluate the likely impact of different reforms through rigorous empirical research. Some of the proposed reforms may not have the effects Tamanaha anticipates, or may come with unforeseen drawbacks. Others may turn out to be beneficial. These are ultimately empirical questions, and we will be interested to see what, if any, changes to legal education emerge as successful in the years to come.

\section{A. Reduce Access to Student Loans}

For example, Professor Tamanaha concludes that the cost of legal education and student loan burdens are the primary barriers preventing law

78 Professor Schlunk might maintain that his discount rate reflects the high risks of a law degree. In The Economic Value of a Law Degree, we find that law degrees are good investments even at the low end of returns. Risk to law students is further reduced through loan forgiveness programs available to low-income graduates, while risk to taxpayers is mitigated through high student loan interest rates, low default rates, and progressive taxation of successful graduates.

79 Chen, supra note 71, at 1191.

80 See, e.g., John R. GRaham \& Scott B. SMart, Introduction To Corporate Finance 41 (abr. ed., 3d ed. 2012) (“[A] normal ratio in one industry may be highly unusual in another."); JAMES M. WAHLEn ET. AL, FinANCIAL REPORTING, FinANCIAL StATEMENT ANALYSis, AND VALUATION 247 (7th ed. 2010) (noting that "ratios differ across industries").

81 See generally Chen, supra note 71.

82 Simkovic \& McIntyre Working Paper Version 1, supra note 70, at 45-49. 
graduates from serving the poor ${ }^{83}$ But the After the $J D$ and After the JD II studies do not provide much support for this view. ${ }^{84}$ Even if debt is a deterrent, perhaps all that is needed is to explain better how student loan forgiveness now works. Federal programs cap debt service payments as a share of disposable income and forgive the remaining student loan balance after ten years of public service..$^{85}$ The higher students' debt levels, the more valuable debt forgiveness and the more attractive public interest work becomes relative to private practice. If law schools were to charge more and student debt levels were to increase, public interest work would become more financially attractive relative to private practice. ${ }^{86}$ Tamanaha's revenue-cutting proposal also may devalue the law schools' own internally funded debt-forgiveness programs, which subsidize low-income graduates working in the public sector. Professor Tamanaha's proposed reformscutting law school tuition to reduce debt and capping federal student loans to law students - would effectively reduce government and law school subsidies to public interest work and would make law graduates more likely to prefer lucrative jobs in the private sector.

Tamanaha's proposals risk reducing the relative attractiveness of public service by converting programs that make subsidies contingent on public service into ones that provide subsidies to all. ${ }^{87}$

The most plausible reason that many law graduates prefer private practice over public service is not that they are overburdened with debt, but rather that the pay differential is simply too large. It is not surprising thatgiven a choice between serving the poor and working for the rich-many

83 See TAMANAHA, supra note 1, at 134 ("Current law graduates are compelled by their debt to seek corporate law jobs that many do not otherwise desire.").

84 See supra note 63 and accompanying text.

85 Public Service Loan Forgiveness Program, FeD. STUDENT AID (Dec. 2013), http://studentaid.ed.gov/sites/default/files/public-service-loan-forgiveness.pdf. Graduates working in the private sector are eligible for debt forgiveness after twenty to twenty-five years, and those whose incomes are too high relative to their debts are ineligible. See Income-Based Plan, FED. STUDENT AID, http://studentaid.ed.gov/repay-loans/understand/plans/income-based (last visited Jan. 14, 2014); Pay as You Earn Plan, FED. STUDENT AID, http://studentaid.ed.gov/repay-loans/understand/plans/pay-as-youearn (last visited Jan. 14, 2014).

${ }^{86}$ Law schools' abilities to cross-subsidize public interest work may be limited by competition between law schools for students. Students interested in private sector work would likely avoid a law school that increased tuition too much to try to subsidize public interest work.

87 One small study of New York University (NYU) law students found that students who received a tuition discount, contingent on working in public interest, were more likely to enroll at NYU and to work in public interest than those who received economically similar debt repayment assistance through NYU, also contingent on public interest work. Erica Field, Educational Debt Burden and Career Choice: Evidence from a Financial Aid Experiment at NYU Law School, AM. ECON. J.: APPLIED ECON., Jan. 2009, at 1. This study does not support Tamanaha's policy prescription because tuition reduction was contingent on public interest work - the student would be forced to repay the tuition discount if he or she worked in the private sector. This is distinct from the unconditional tuition reduction proposed by Tamanaha. At the time of the NYU study, federal income contingent debt forgiveness programs were not available, and these were implemented prospectively. 
law graduates would prefer to eat well, dress well, live in good neighborhoods, and purchase good health care and education for themselves and their children. Many Americans would prefer the same things, if they were fortunate enough to have the same opportunities. ${ }^{88}$

Tamanaha does suggest one interesting option to reduce student debt burdens. Universities could begin financing their own law students rather than relying on the federal government or private lenders to do so. ${ }^{89}$ Leaving aside concerns about scale, expertise, and diversification of risk, this suggestion is promising. Law graduates have high incomes and relatively low default rates. Federal student loans to graduate students - in particular Grad Plus loans-are relatively expensive. A lender with low customer acquisition and administrative costs could potentially undercut the federal government's prices, reduce students' financing costs, and still turn a profit on the loans. ${ }^{90}$

\section{B. Reduce Faculty Resources}

Tamanaha concludes that faculty compensation, research support, and tenure protections can be reduced without any long-term impact on the quality of instruction at law schools. This assertion is based in part on his belief that "law professors have been doing swimmingly well compared to most lawyers for some time now." 91

But Tamanaha's claim that most law faculty earn more than most lawyers is incorrect. To the contrary, law professors earn less than lawyers at every point in the earnings distribution. Figure 3 below shows earnings at the tenth, twenty-fifth, fiftieth, and seventy-fifth percentiles and at the mean for lawyers and law professors. All data comes from the U.S. Department of Labor Bureau of Labor Statistics, Occupational Employment Statistics. ${ }^{92}$ Tamanaha uses this data for lawyer earnings, but he overlooks the availability of law professor earnings from the same source. ${ }^{93}$

\footnotetext{
88 Indeed, Professor Tamanaha concludes that recipients of merit scholarships are the most likely to secure high-paid jobs, notwithstanding merit scholars' low debt burdens. TAMANAHA, supra note 1, at 98.

89 Id. at 180.

90 See Michael Simkovic, Risk-Based Student Loans, 70 WASH. \& LEE L. REV. 527, 606-07 (2013).

91 TAMANAHA, supra note 1 , at 48.

92 Data are inflation adjusted to 2013.

93 See id. at 50-51.
} 
Figure 3: LAW Professors EARN Less than LAWYers-EARNingS by OCCUPATION, 2012

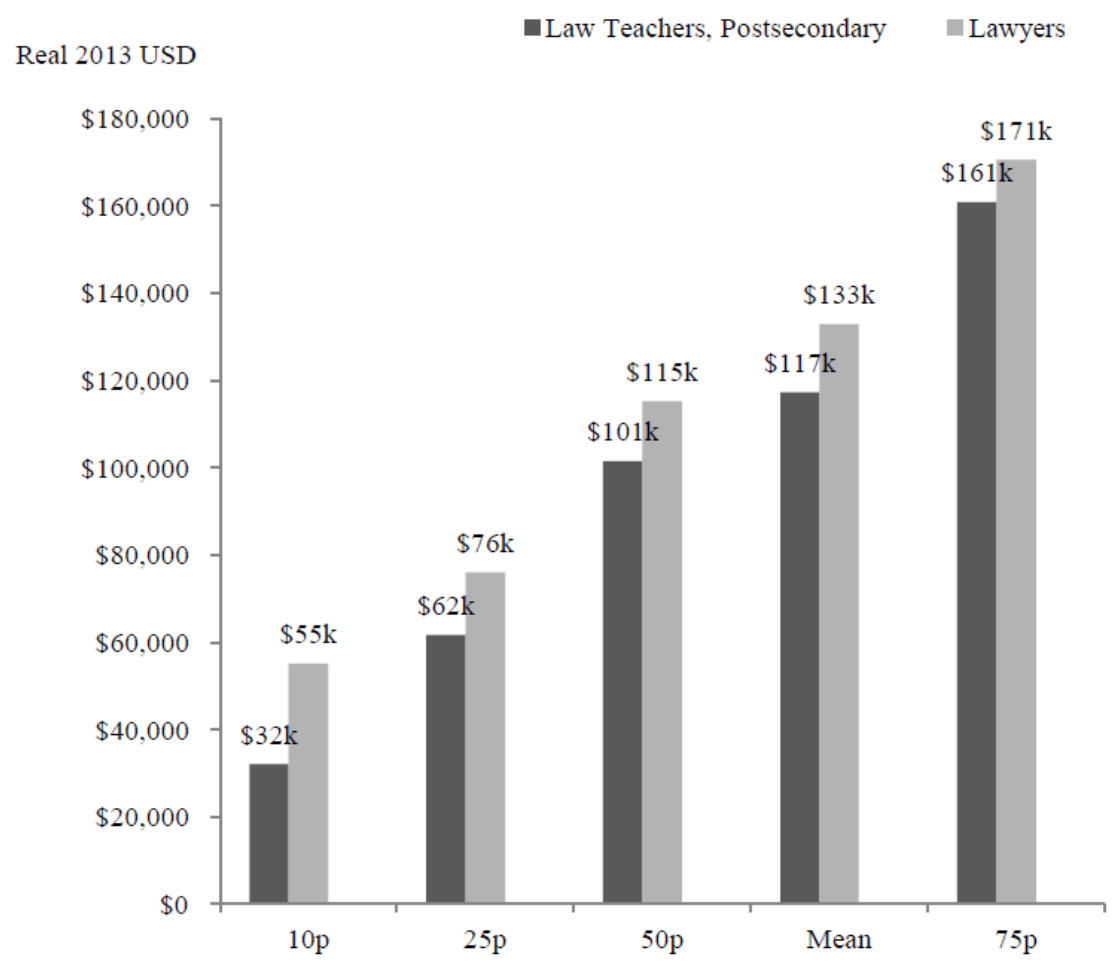

Source: U.S. Department of Labor Bureau of Labor Statistics, Occupational Employment Statistics; Consumer Price Index (CPI).

Note: Lawyers excludes law firm partners and solo practitioners.

Earnings for law professors are lower than those for lawyers, even though the lawyer data excludes high-earning law firm partners ${ }^{94}$ and many of the lawyers will have less work experience than law professors. ${ }^{95}$ Moreover, observable differences between future law professors and future lawyers in academic performance, caliber of law school attended, and credentials, such as federal judicial clerkships, ${ }^{96}$ suggest that the typical law professor could

94 See supra note 53 and accompanying text.

95 Median lawyer age is roughly forty-nine-although as noted above, the Bureau of Labor Statistics group will likely be younger because it excludes solo practitioners and partners-while median law faculty age is fifty-six to sixty. See 2008-2009 AALS Statistical Report on Law Faculty, Gender and Age, Ass'N AM. L. SCHOOLS (2009), http://www.aals.org/statistics/2009dlt/gender.html; Lawyer Demographics, A.B.A. (2012), http://www.americanbar.org/content/dam/aba/migrated/marketresearch/ PublicDocuments/lawyer_demographics_2012_revised.authcheckdam.pdf.

96 See Donna Fossum, Law Professors: A Profile of the Teaching Branch of the Legal Profession, 1980 AM. B. Found. RES. J. 501; Daniel Martin Katz et al., Reproduction of Hierarchy? A Social Network Analysis of the American Law Professoriate, 61 J. LEGAL EduC. 76 (2011); 2008-2009 AALS 
probably have earned more than the typical lawyer if the professor had chosen to practice law instead of teaching.

Tamanaha presents a distorted view of law faculty compensation by focusing on the pinnacle of the profession-faculty at elite law schools, the highest paid law school deans, and tenured full professors who typically have decades of work experience and are near peak earnings. ${ }^{97}$ Most law professors earn far less for most of their academic careers. Tamanaha also confuses "full" professors - the most senior, experienced, and highly paid professors who have obtained tenure - with "full-time" professors - those whose full-time job is working as a professor, including lower paid assistant, associate, and nontenure-track faculty. ${ }^{98}$ Because of these errors, Tamanaha dramatically overestimates typical law professor earnings, and therefore underestimates the opportunity cost of choosing law teaching over law practice.

This does not necessarily mean that law professors are undercompensated. As Tamanaha rightly notes, lower earnings may reflect a compensating differential for more pleasant work. ${ }^{99}$ But he fails to appreciate that the existing wage structure already incorporates differences between the kinds of work performed by lawyers and law professors.

Tamanaha's claim that faculty compensation could be dramatically reduced without any long-term impact on the quality of legal education seems unlikely. Several empirical studies have examined the role of faculty compensation in recruitment and retention at the undergraduate level. They find that universities must offer compensation that is reasonably competitive with that available in the private sector or face shortages of qualified instructors in high-value, high-wage fields. ${ }^{100}$

Statistical Report on Law Faculty, Faculty with JD/LLB Degrees from AALS Affiliated Law Schools, Ass'N AM. L. SCHOOLS (2009), http://www.aals.org/statistics/2009dlt/JD.pdf.

97 TAMANAHA, supra note 1 , at 48-50.

98 Id. at 49 ("According to ... SALT, the average median salary of full-time professors in 2008-9 was $\$ 147,000$....” (emphasis added)); cf. 2008-09 SALT Salary Survey, SALT EQUALIZER (Soc'y of Am. Law Teachers, St. Paul, Minn.), Mar. 2009, at 1.

99 See TAMANAHA, supra note 1 , at 187.

100 See, e.g., Richard B. FreEMAN, THE MARKET FOR COLlEge-Trained MANPOWER: A STUDY IN THE ECONOMICS OF CAREER CHOICE 165-67 (1971) (documenting shortages of faculty in highdemand fields in the United States in the 1960s); MiKe HorSLEy ET AL., Oval ReSEARCh CENTRE, SALARY RELATIVITIES AND THE ACADEMIC LABOUR MARKET 47-79 (n.d.), available at http://docs.glotta.ntua.gr/International/academic_salaries.pdf (documenting Australian universities' difficulty hiring faculty when candidates were qualified for more highly paid private sector work); Ronald Ehrenberg et al., Faculty Turnover at American Colleges and Universities: Analyses of AAUP Data, 10 ECON. EdUC. REV. 99, 99-110 (1991) (confirming the importance of salary to faculty retention); Faculty Salaries Vary by Institution Type, Discipline, Chron. Higher Educ. (Apr. 11, 2011), http://chronicle.com/article/Faculty-Salaries-Vary-by/127073 (presenting data showing that faculty salaries are highest in law, business, economics, computer science, engineering, and health science, and lowest in performing arts, education, and the humanities). 
Law professors in technical fields are drawn from the same pool of talent as doctors, lawyers, bankers, consultants, corporate executives, and government officials. Except for a small minority, they are motivated at least in part by compensation. While senior faculty may find it difficult to retrain for a different occupation, high-performing recent college and law school graduates can and will choose other occupations if faculty compensation and opportunities for research are reduced too much, and the quality of personnel at law schools will decline.

Professors place a high monetary value on tenure, and a university that unilaterally eliminated tenure would either have to pay more or suffer a loss in faculty quality. After controlling for faculty quality, university rank, and cost of living, university economics departments that are less likely to offer faculty tenure must pay untenured faculty more, in part to compensate for increased risk. ${ }^{101}$

Despite the well-known problems of tenure, some claim that it can actually enhance efficiency from an institutional perspective because it encourages senior faculty to share their knowledge and hire the most talented junior faculty rather than attempt to protect their turf from potential competitors. ${ }^{102}$ Tenure also encourages faculty to invest in highly specialized knowledge ${ }^{103}$ and compete in a winner-take-all tournament. ${ }^{104}$ Whether this is enough to counterbalance post-tenure incentive problems remains to be seen.

Empirical studies show that the most highly qualified faculty value low teaching loads and academic prestige. ${ }^{105}$ This suggests that highly talented faculty may be unlikely to agree to teach heavy loads at low-ranked (i.e., nonresearch) institutions unless they are well-compensated financially.

Professor Tamanaha concludes that low-cost, untenured, part-time, or adjunct faculty can be used to bring down costs without much loss to instructional quality. ${ }^{106}$ Empirical studies have examined instructional

101 Ronald G. Ehrenberg et al., Do Economics Departments with Lower Tenure Probabilities Pay Higher Faculty Salaries?, 80 REV. ECON. \& STAT. 503 (1998). The study found that higher tenure standards may also increase pay because they increase reliance on lateral hires and motivate faculty to be more productive. Id. at 503-04.

102 Ronald G. Ehrenberg, Rethinking the Professoriate 5 (Cornell Univ. Sch. of Indus. \& Labor Relations, Working Paper, 2010), available at http://digitalcommons.ilr.cornell.edu/cgi/ viewcontent.cgi article $=1142 \&$ context=workingpapers.

103 See Michael S. McPherson \& Gordon C. Winston, The Economics of Academic Tenure: A Relational Perspective, in Michael S. McPherson et Al., Paying the PiPer: Productivity, INCENTIVES, AND FINANCING IN U.S. HIGHER EDUCATION 109, 110, 115-19 (1993).

104 See Aloysius Siow, The Organization of the Market for Professors 18 (Univ. of Toronto Dep't of Econ. \& Inst. for Policy Analysis, Working Paper No. UT-ECIPA-SIOW-95-01, 1995).

105 See Edward R. Morey \& Jennifer A. Thacher, Using Choice Experiments and Latent-Class Modeling to Investigate and Estimate How Academic Economists Value and Trade Off the Attributes of Academic Positions 27 (Nov. 26, 2012) (unpublished manuscript), available at http:// www.colorado.edu/economics/morey/papers/MoreyThacher_LCFaculty_withTables.pdf.

106 See TAMANAHA, supra note 1, at 12, 44, 174, 182. 
staffing at four-year bachelor's degree programs and community colleges. Although it is unclear if the results are generalizable to low-cost law schools, the data generally do not support Tamanaha's views.

When four-year colleges increase the use of either full-time, nontenure-track faculty or part-time faculty, most studies find that undergraduate students become more likely to drop out in their first year and less likely to graduate. ${ }^{107}$ Similarly, increased use of part-time faculty by community colleges appears to reduce the likelihood that students will either complete an associate's degree or transfer to a four-year college. ${ }^{108}$ Worse outcomes for students of adjuncts and part-time faculty may be due in part to the heavy teaching loads that such faculty must take on, sometimes at multiple institutions, to make ends meet. ${ }^{109}$

Different outcomes may also be explained in part by differences in job security between full-time, tenured research professors and adjuncts. Adjuncts typically give higher grades than full-time faculty, apparently because they face greater pressure to obtain high course evaluations so that their contracts will be renewed. ${ }^{110}$ Professors can increase enrollments and boost course evaluations by assigning better grades for less work because students actively shop for such classes. ${ }^{111}$ Students also give better course evaluations to professors who grade more generously and who flatter students - and worse evaluations to those who demand more work and more substantive learning. ${ }^{112}$

107 See, e.g., Eric P. Bettinger \& Bridget Terry Long, The Increasing Use of Adjunct Instructors at Public Institutions: Are We Hurting Students?, in WHAT's HAPPENING TO PUBLIC HighER EdUCATION? 51, 51, 68 (Ronald G. Ehrenberg ed., 2006); Ronald G. Ehrenberg, American Higher Education in Transition, J. ECON. PERSP., Winter 2012, at 193; Ronald G. Ehrenberg \& Liang Zhang, Do Tenured and Tenure-Track Faculty Matter?, 40 J. HuM. RESOURCES 647 (2005); cf. Eric P. Bettinger \& Bridget Terry Long, Does Cheaper Mean Better? The Impact of Using Adjunct Instructors on Student Outcomes, 92 REV. ECON. \& STATS. 598, 608-09 (2010).

108 M. Kevin Eagan Jr. \& Audrey J. Jaeger, Effects of Exposure to Part-Time Faculty on Community College Transfer, 50 RES. HigHER EDUC. 168 (2009) (explaining the negative effects on the likelihood of transferring); Daniel Jacoby, Effects of Part-Time Faculty Employment on Community College Graduation Rates, 77 J. HIGHER EDUC. 1081 (2006) (explaining the negative effects on graduation rates); Audrey J. Jaeger \& M. Kevin Eagan, Jr., Unintended Consequences: Examining the Effect of Part-Time Faculty Members on Associate's Degree Completion, 36 CommuniTY. C. REV. 167 (2009) (explaining the negative effects on probability of completing an associate's degree).

109 Ehrenberg, supra note 102, at 7.

110 Brenda S. Sonner, A Is for "Adjunct”: Examining Grade Inflation in Higher Education, 76 J. EDUC. FOR BUS., Sept.-Oct. 2000, at 5, 7.

111 Talia Bar et al., Grade Information and Grade Inflation: The Cornell Experiment, J. ECON. PERSP., Summer 2009, at 93, 101-02 (presenting evidence "that the provision of [average] grade [and grade distribution] information [to Cornell students] led to increased enrollment into leniently graded courses" and that students of high ability were less likely than students of lower ability to pursue courses with more lenient grading).

112 See Scott E. Carrell \& James E. West, Does Professor Quality Matter? Evidence from Random Assignment of Students to Professors, 118 J. POL. ECON. 409, 412, 430 (2010). 
Education is a complex market with known principal-agent problems. Tamanaha proposes reducing licensing and accreditation standards and letting students decide for themselves which classes to take. ${ }^{113}$ But treating students as customers could reduce rigor because many professors, particularly those who are insecure about their jobs, respond to such incentives by easing classroom workloads and inflating grades. ${ }^{114}$ The result may be that student customers study less, learn less, and are less prepared for the professional world. ${ }^{115}$

Anecdotal evidence suggests that at current compensation levels, nonelite law schools struggle to find qualified full-time, tenure-track instructors in technical areas that are valued in the labor market. This includes fields such as taxation, financial regulation, patents, energy, health care, bankruptcy, and commercial law. ${ }^{116}$ But it is precisely these areas that offer the most lucrative employment opportunities for law graduates and where law schools committed to providing a high earnings premium should be expanding their course offerings and full-time faculty. ${ }^{117}$

\section{Shorter, Deregulated Legal Education}

Professor Tamanaha advocates two-year law degrees as a bold reform that he anticipates the legal establishment will resist. ${ }^{118}$ However, under the current system, only one year of law school is necessary to practice law in the largest legal markets, New York and California. ${ }^{119}$ To sit for the bar

113 TAMANAHA, supra note 1, at 174 ("Prospective students will be able to pick the legal education program they want at a price they can afford.").

114 See Donald Larry Crumbley et al., What Is Ethical About Grade Inflation and Coursework Deflation?, 8 J. ACAD. ETHICS 187, 187 (2010) (arguing that course evaluations have "caused grade inflation, coursework deflation, and a reduction in student learning as a result of unethical behavior of professors and administrators"); David A. Love \& Matthew J. Kotchen, Grades, Course Evaluations, and Academic Incentives, 36 E. ECON. J. 151, 151 (2010) (modeling professor behavior and suggesting that increased emphasis on course evaluations can lead to grade inflation).

115 See generally Philip Babcock, Real Costs of Nominal Grade Inflation? New Evidence from Student Course Evaluations, 48 ECON. INQUIRY 983 (2010) (providing evidence that higher nominal grades (i.e., grade inflation) can dramatically reduce student effort and study time).

116 One of us knows several gifted and scholarly practitioners who have turned down opportunities to become full-time professors because of inadequate compensation, as well as several law schools that reluctantly use adjuncts or faculty who specialize in other areas to teach classes in these areas.

117 See, e.g., Hillary Mantis, Practice Areas that Are Hiring, NAT'L JURIST (Feb. 15, 2013), http://www.nationaljurist.com/content/practice-areas-are-hiring; Michael Morella, Consider a Legal Career in Health or Intellectual Property, U.S. NEwS \& WORLD REP. (Mar. 13, 2012), http://www.usnews.com/education/best-graduate-schools/top-law-schools/articles/2012/03/13/considera-legal-career-in-health-or-intellectual-property; Christina Thomas, Intellectual Property, Patent Litigation Still a Hot Practice Area, NAT'L JURIST, (Jan. 11, 2013), http://www.nationaljurist.com/ content/intellectual-property-patent-litigation-still-hot-practice-area.

118 TAMANAHA, supra note 1 , at 172-76.

119 Tamanaha obliquely notes that "[a] handful of states, which have their own accreditation procedures, do not require graduation from an ABA accredited law school for admission to their bar" and concludes that "if the states with the largest legal markets were to do so, tuition at the lower-ranked 
exam in these states, applicants need only complete a minimum of one year of law school and then apprentice with a lawyer. ${ }^{120}$ Tamanaha advocates something similar as a national model, but he presents no information on how outcomes for those who have pursued prebar apprenticeships in lieu of the second or third year of law school compare to outcomes for graduates of traditional law schools.

Perhaps such apprenticeship-trained lawyers would be difficult to study because they are rare. But if students and employers do not use the apprenticeship model in states where it is already available-or if those who do use it disproportionately fail the bar exam ${ }^{121}$ - what will be accomplished by introducing it nationally? Perhaps there is a version of such a program that will work, but as of now, few avail themselves of the option.

Professor Tamanaha praises low-cost and unaccredited law schools, ${ }^{122}$ but he neglects to systematically evaluate whether low net tuition reflects efficiency, differences in state subsidies, ${ }^{123}$ or inferior quality contributing to worse student outcomes after controlling for differences in student characteristics. ${ }^{124}$ Among nonprofit universities, colleges with higher tuition prices generally spend more on instruction per student, and, after controlling for student characteristics, their graduates appear to earn more money. ${ }^{125}$

law schools would fall." Id. at 176-77. But California and New York are the two states with the largest legal markets by total employment and earnings for lawyers, collectively accounting for more than $23 \%$ of employment and $27 \%$ of earnings. See Occupational Employment and Wages, May 2012, 23-1011 Lawyers, BUREAU LAB. STAT., http://www.bls.gov/oes/current/oes231011.htm (last modified Mar. 29, 2013).

120 CAL. Bus. \& Prof. CODE $§ 6060$ (West 2003); N.Y. CT. R. $\$ 520.4$.

121 Raw data from the National Conference of Bar Examiners suggests that those who read for the bar exam or attend non-ABA-accredited law schools have lower bar passage rates. See Bar Examination and Admission Statistics, NAT'L CONF. B. EXAMINERS, http://www.ncbex.org/publications/statistics (last visited Jan. 14, 2014).

122 TAMANAHA, supra note 1 , at 12, 18-19, 184-85.

123 Tamanaha condemns Berkeley, Michigan, Virginia, and UCLA because he thinks that they "abdicated their public mission in order to pursue rankings, following the expensive private researchuniversity model." Id. at 184 . But Professor Tamanaha fails to systematically consider how changes in level of taxpayer support per student may drive tuition increases and cost/quality tradeoffs at state schools.

124 Professor Tamanaha notes that one low-ranked law school's tuition increased after it was taken over by a for-profit company and gained accreditation, but he neglects to consider whether the increase in pricing might be for a reason other than market power conferred by accreditation, for example, the tendency of for-profit managers to try to maximize profit. See id. at 18-19; see also id. at 197 n.27 (acknowledging that unaccredited law schools have lower bar passage rates than accredited law schools, but attributing this to differences in student characteristics - without presenting any data on underlying student characteristics or citing or performing any formal empirical analysis).

125 Stacy Berg Dale \& Alan B. Krueger, Estimating the Payoff to Attending a More Selective College: An Application of Selection on Observables and Unobservables, 117 Q. J. ECON. 1491, 1524 (2002) ("We do find that students who attend colleges with higher average tuition costs tend to earn 


\section{LOW-COST SOLUTIONS THAT TAMANAHA OPPOSES}

Professor Tamanaha wants more low-cost options for legal education, ${ }^{126}$ but he denigrates many low-cost opportunities currently available to law students.

Thanks to aggressive competition between law schools for students with high grades and test scores, students with above-average abilities often can benefit from tuition discounting by attending a lower ranked institution. ${ }^{127}$ Such scholarships enable students to obtain a legal education at low or no direct cost, enable students of limited means but strong motivation and ability to attend law school, and reward law schools that provide such scholarships with a higher ranking and a more vibrant community. But to Professor Tamanaha, merit-based scholarships are "malign," 128 "indefensible," 129 and "help[] the wealthy consolidate their grip on elite legal positions." 130

Tamanaha overlooks the possibility that differences in outcomes between graduates of different law schools may simply be due to differences in the abilities of the incoming students. ${ }^{131} \mathrm{He}$ also overlooks the possibility that peer effects from high performers may help lower performing classmates, ${ }^{132}$ instead viewing law school as a zero-sum competition.

Opportunity costs can be minimized by attending law school part-time or at night while working a full-time job. According to the 2014 ABA-LSAC Official Guide to ABA-Approved Law Schools, more than a hundred ABAapproved law schools offer part-time programs. ${ }^{133}$ But Professor Tamanaha condemns law schools for opening part-time programs to students who are

higher income years later, after adjusting for student characteristics. . . . [T] uition matters because higher cost schools devote more resources to student instruction.").

126 See TAMANAHA, supra note 1, at 172-75.

127 Almost all ABA-approved law schools offer at least some scholarships that cover half or full tuition. At twenty-five law schools, $30 \%$ or more of full-time students receive such large scholarships. 2014 ABA-LSAC Official Guide to ABA-Approved Law Schools, LSAC, https://officialguide.lsac.org/ release/OfficialGuide_Default.aspx (last visited Jan. 14, 2014).

128 TAMANAHA, supra note 1 , at 99.

129 Id. at 98

$130 I d$. at 134 .

131 Dale \& Krueger, supra note 125, at 1523 (finding that college selectivity does not predict higher earnings after controlling for student ability levels); Richard Sander \& Jane Bambauer, The Secret of My Success: How Status, Eliteness, and School Performance Shape Legal Careers, 9 J. EMPIRICAL LEGAL STUD. 893 (2012) (finding that earnings and likelihood of making partner depends more on individual law school grades than on institutional law school prestige); $c f$. Oyer \& Schaefer, supra note 74.

132 See Gordon C. Winston \& David J. Zimmerman, Peer Effects in Higher Education, in COLLEGE Choices: The ECONOMics of Where to Go, When to Go, AND How to PAY FOR It 395, 418 (Caroline M. Hoxby ed., 2004); Ron Zimmer, A New Twist in the Educational Tracking Debate, 22 ECON. EDUC. REV. 307, 313-14 (2003).

1332014 ABA-LSAC Official Guide to ABA-Approved Law Schools, supra note 127. 
not necessarily working full-time but are academically less well-prepared than full-time students. Tamanaha faults law schools for "stigmatizing" part-time students and using part-time programs to exploit "a loophole" in U.S. News rankings. ${ }^{134} \mathrm{He}$ dismisses the possibility that some students may benefit from a slower pace in their first year of law school as "hooey,"135 and overlooks the possibility that part-time programs may need a minimum number of students to be financially viable.

\section{CONCLUSION}

Tamanaha's attack on legal education comes at a time of economic recession. The challenging employment market faced by recent law graduates is likely not the result of long-term problems in legal education, but rather is a direct result of broader economic problems that are having an even harsher impact on those with less education. It is unfortunate if some students relying on faulty information have made the costly decision to terminate their educations with bachelor's degrees when they would have benefited handsomely from a law degree.

Like all institutions, law schools are far from perfect. They must continuously strive to improve, to expend fewer resources in areas with low rates of return, and to focus more resources in areas that can do the most good for their students and for the rest of society. Educational institutions can be slow to move, and we hope Professor Tamanaha's advocacy will focus greater attention on efficiency and productive use of resources. Constructive reforms, however, must be built on good data, rigorous analysis, and an accurate understanding of the status quo ante. Whatever one's preference for change, the data is clear: law schools typically provide both law students and the federal government an attractive rate of return on investment.

\footnotetext{
134 TAMANAHA, supra note 1 , at 86.

135 Id.
} 